\title{
Hypoparathyroidism: clinical features, skeletal microstructure and parathyroid hormone replacement
}

\author{
Hipoparatiroidismo: aspectos clínicos, microestrutura \\ esquelética e reposição do paratormônio
}

Mishaela R. Rubin', John P. Bilezikian'

1 Unidade de Doenças Metabólicas Ósseas, Divisão de Endocrinologia, Departamento de Medicina, College of Physicians and Surgeons, Columbia University, Nova York, Estados Unidos

\author{
Correspondence to: \\ John P. Bilezikian \\ Division of Endocrinology \\ Department of Medicine \\ College of Physicians and \\ Surgeons \\ 630 W. 168th Street \\ 10032 - New York, NY, United \\ States \\ jpb2@columbia.edu
}

Received on Nov/20/2009 Accepted on Feb/28/2010

\begin{abstract}
Objective: Hypoparathyroidism is a disorder in which parathyroid hormone is deficient in the circulation due most often to immunological destruction of the parathyroids or to their surgical removal. The objective of this work was to define the abnormalities in skeletal microstructure as well as to establish the potential efficacy of PTH(1-84) replacement in this disorder. Subjects and methods: Standard histomorphometric and $\mu \mathrm{CT}$ analyses were performed on iliac crest bone biopsies obtained from patients with hypoparathyroidism. Participants were treated with PTH(1-84) for two years. Results: Bone density was increased and skeletal features reflected the low turnover state with greater BV/TV, Tb. Wi and $\mathrm{Ct}$. Wi as well as suppressed MS and BFR/BS as compared to controls. With PTH(1-84), bone turnover and bone mineral density increased in the lumbar spine. Requirements for calcium and vitamin $D$ fell while serum and urinary calcium concentrations did not change. Conclusion: Abnormal microstructure of the skeleton in hypoparathyroidism reflects the absence of PTH. Replacement therapy with PTH has the potential to correct these abnormalities as well as to reduce the requirements for calcium and vitamin $\mathrm{D}$. Arq Bras Endocrinol Metab. 2010;54(2):220-6
\end{abstract}

\section{Keywords}

Calcium; hypoparathyroidism; parathyroid hormone; vitamin D; bone density

\section{RESUMO}

Objetivo: O hipoparatiroidismo é uma doença em que há diminuição dos níveis circulantes do paratormônio, em geral, causada por destruição autoimune ou exerese cirúrgica. 0 objetivo deste estudo foi descrever as anormalidades microestrutrurais esqueléticas, como também o potencial terapêutico do uso do PTH(1-84). Sujeitos e métodos: Histomorfometria padrão e análise de micro-CT foram realizadas em biópsias de crista ilíaca de indivíduos com hipoparatiroidismo. Os participantes foram tratados com PTH(1-84) por dois anos. Resultados: A densidade óssea aumentou e os achados esqueléticos refletiram o estado de baixa remodelação óssea com maior BV/TV, Tb Wi e CTWi, como também supressão de MS e BFR/BS quando comparado com o grupo controle. Com o uso de PTH(1-84), a remodelação óssea aumentou e a densidade óssea aumentou na coluna lombar. As necessidades de cálcio e vitamina $\mathrm{D}$ diminuíram e a calciúria não mudou. Conclusão: A microestrutura esquelética anormal no hipoparatiroidismo reflete a ausência do PTH. A terapia de reposição com PTH tem o potencial de reverter essas anormalidades, como também reduzir as necessidades de cálcio e vitamina D. Arq Bras Endocrinol Metab. 2010;54(2):220-6

\section{Descritores}

Cálcio; hipoparatiroidismo; paratormônio; vitamina D; densidade óssea 
$\mathrm{H}_{\mathrm{h}}^{\text {pon }}$ ypoparathyroidism is a disorder of parathyroid hormone (PTH) deficiency caused by two main etiologies (1-4). Autoimmune destruction of the parathyroid glands can occur as an isolated endocrine deficiency syndrome or in connection with failure of other endocrine glands. The other common etiology of hypoparathyroidism is after neck surgery in which all parathyroid tissue is removed, either in the context of surgery for primary hyperparathyroidism or after extensive neck surgery for thyroid cancer. The hypoparathyroidism that occurs after neck surgery does not always present itself soon, post-operatively, but rather can become apparent months to years thereafter. Although these two causes of hypoparathyroidism constitute the vast majority of patients with this disorder, it can also occur as a congenital disorder in which the parathyroids and other derivatives of the $3^{\text {rd }}$ and $4^{\text {th }}$ pharyngeal pouches do not develop (DiGeorge syndrome). Very rarely, intracellular processing defects or activating mutations of the calcium sensing receptor can lead to hypoparathyroidism (5-7).

\section{CLINICAL FEATURES}

The clinical features of hypoparathyroidism, when symptomatic, can include any of the following: circumoral numbness, paresthesias, carpal and pedal muscle spasms, laryngeal spasm, tetany and/or seizures (4). These symptoms are associated with the classical biochemical constellation of hypocalcemia and low levels of PTH. On the other hand, patients with hypoparathyroidism can be asymptomatic, in which only the biochemical hallmarks of the disease are apparent. The combination of low serum calcium concentration and low or undetectable PTH levels essentially rules out all other causes of hypocalcemia (such as vitamin D deficiency, malabsorption syndrome, renal disease) in which the hypocalcemia is typically accompanied by normal compensatory physiological hyperactivity of the parathyroid gland axis and elevated PTH levels. Other biochemical abnormalities that often accompany the hypoparathyroid state include hyperphosphatemia, hypercalciuria and reduced levels of 1,25-dihydroxyvitamin D, all consequences of PTH deficiency.

This article focuses upon our experience with a cohort of subjects with well-documented hypoparathyroidism. Our study population was similar to the expected demographics of hypoparathyroidism with autoimmune and postoperative hypoparathyroidism constituting, by far, the two most common causes. Duration of hypo- parathyroidism ranged from 3-45 years. Although none of the subjects had classic fragility fractures, $1 / 4$ had reported mild fractures, mostly in small bones, during adulthood. Basal ganglia calcifications were found on prior radiologic imaging in 4 subjects, although this aspect of hypoparathyroidism was not specifically sought. Baseline biochemical values are shown in table 1. All subjects were receiving calcium and vitamin D.

We and others have shown (Table 2) that bone mass, by dual energy X-ray absorptiometry (DXA), is generally substantially higher in hypoparathyroidism than in ageand sex-matched controls (8-12). This observation contrasts markedly with bone mass measurements by DXA in primary hyperparathyroidism in which bone density of the distal $1 / 3$ radius, a site of cortical bone, is typically reduced (13). The general increase in bone mass in hypoparathyroidism is associated with low levels of bone turnover as assessed by circulating biochemical markers and by dynamic histomorphometry (see below).

Table 1. Characteristics of patients with hypoparathyroidism

\begin{tabular}{|c|c|c|}
\hline & $N=33$ & Range \\
\hline \multirow[t]{2}{*}{ Age (yrs) } & $48.2 \pm 12$ & $25-68$ \\
\hline & $\begin{array}{c}\text { Male: } 9 \\
\text { Female: } 24 \\
\text { (Premenopausal: } 14 \\
\text { Postmenopausal: } 10 \text { ) }\end{array}$ & \\
\hline Etiology & $\begin{array}{c}\text { Postoperative: } 18 \\
\text { Autoimmune: } 13 \\
\text { DiGeorge: } 2\end{array}$ & \\
\hline Duration of hypoparathyroidism (yrs) & $17 \pm 13$ & $3-45$ \\
\hline Calcium supplement dose (mg) & $3024 \pm 2227$ & $0-9000$ \\
\hline Calcitriol supplement dose (mcg) & $0.75 \pm 0.6$ & $0-3$ \\
\hline Daily vitamin $D$ dose $(I U) n=15$ & $12,026 \pm 26,299$ & $400-100,000$ \\
\hline Thiazide dose $(\mathrm{mg}) \mathrm{n}=10$ & $25 \pm 11$ & $6.25-50$ \\
\hline Fractures in adulthood (\# of patients) & $\begin{array}{l}8 \text { ( } 4 \text { metatarsal, } 4 \text { toe, } 2 \\
\text { digit, } 1 \text { hand, } 1 \text { thumb) }\end{array}$ & \\
\hline Kidney stones (\# of patients) & 5 & \\
\hline $\begin{array}{l}\text { Basal ganglia calcifications } \\
\text { (\# of patients) }\end{array}$ & 4 & \\
\hline
\end{tabular}

Table 2. Baseline hypoparathyroid bone mineral density (mean \pm SD). Each subject measured twice

\begin{tabular}{lccc}
\hline & & & Cohort range \\
\hline Lumbar spine & BMD & $1.21 \pm 0.21$ & $(0.794,2.028)$ \\
& T-score & $1.35 \pm 1.88$ & $(-2.541,8.912)$ \\
Femoral neck & BMD & $0.93 \pm 0.17$ & $(0.554,1.390)$ \\
Total hip & T-score & $0.51 \pm 1.44$ & $(-2.659,4.370)$ \\
& BMD & $1.06 \pm 0.16$ & $(0.654,1.455)$ \\
Distal 1/3 radius & T-score & $0.72 \pm 1.22$ & $(-2.362,4.206)$ \\
& BMD & $0.73 \pm 0.06$ & $(0.545,0.898)$ \\
& T-score & $0.04 \pm 1.01$ & $(-3.315,2.117)$ \\
\hline
\end{tabular}




\section{Skeletal microstructure in hypoparathyroidism}

In order to obtain more information on bone quality in hypoparathyroidism, we have obtained transiliac bone biopsies on most of our patients (14-15). They were matched to age- and sex-matched control subjects who do not have any abnormalities in parathyroid function.

Histomorphometric assessment. Subjects with hypoparathyroidism had greater trabecular bone volume (mean \pm SD; BV $/$ TV: $23.5 \pm 8$ vs. $19.7 \pm 5 \%, \mathrm{p}=0.02$ ), trabecular width (Tb.Wi: $136.1 \pm 37 v s .119 .3 \pm 21 \mu \mathrm{m}$, $\mathrm{p}=0.03$ ), and cortical width (Ct.Wi: $923.4 \pm 420 \mathrm{vs}$. $753.5 \pm 246 \mu \mathrm{m}, \mathrm{p}=0.05$ ) than control subjects (Figure 1A). Dynamic skeletal indices, including mineralizing surface (MS: $0.85 \pm 1.58$ vs. $4.27 \pm 3.32 \%, \mathrm{p}<$ $0.0001)$ and bone formation rate (BFR/BS: $0.006 \pm$ 0.014 vs. $\left.0.032 \pm 0.028 \mu^{3} / \mu \mathrm{m}^{2} / \mathrm{d}, \mathrm{p}<0.0001\right)$, were profoundly suppressed in the hypoparathyroid subjects.

Microcomputed tomography $(\mu C T)$. We extended these 2-dimensional histomorphometric analyses to a 3-dimensional analysis applying $\mu \mathrm{CT}$ to the same biopsies. Appropriate age and sex-matched normal subjects without hypoparathyroidism served as controls. Hypoparathyroid subjects had significantly greater trabecular bone volume (BV/TV: $26.98 \pm 10$ vs. $15.39 \pm 4 \%$ $[$ mean $\pm \mathrm{SD}] ; \mathrm{p}<0.001)$, trabecular number $(\mathrm{Tb} . \mathrm{N}$ : $1.831 \pm 0.49$ vs. $\left.1.355 \pm 0.24 \mathrm{~mm}^{-1} ; \mathrm{p}<0.001\right)$, trabecular thickness (Tb.Th: $0.193 \pm 0.05$ vs. $0.148 \pm 0.02 \mathrm{~mm}$; $\mathrm{p}<0.001$ ) and connectivity density (Conn.D: $15.899 \pm$ 18.40 vs. $\left.4.958 \pm 2.02 / \mathrm{mm}^{3} ; \mathrm{p}=0.001\right)$ in comparison to controls, while trabecular separation (Tb.Sp: 0.642 \pm 0.10 vs. $0.781 \pm 0.13 \mathrm{~mm} ; \mathrm{p}<0.001)$ and estimation of the plate-rod characteristic (SMI: $-0.457 \pm 1.52$ vs. $0.742 \pm 0.51 ; \mathrm{p}<0.001$ ) were significantly lower, the latter observation implying a more plate-like trabecular structure (Figure 1B). These findings support the data obtained by 2 -dimensional histomorphometric analysis indicating that trabecular bone structure in hypoparathyroidism is abnormal.
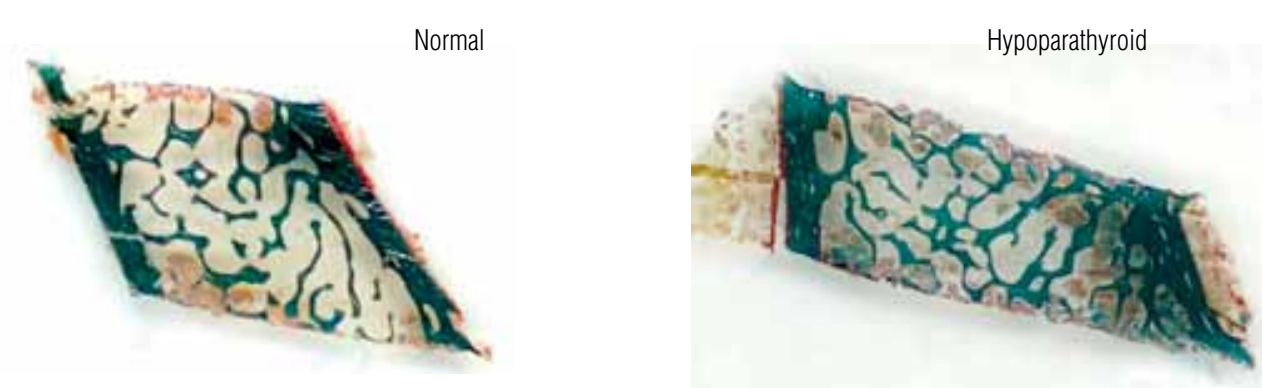

Figure 1A. A representative photomicrograph of an iliac crest biopsy from a normal control (left) as compared to a hypoparathyroid subject (right).
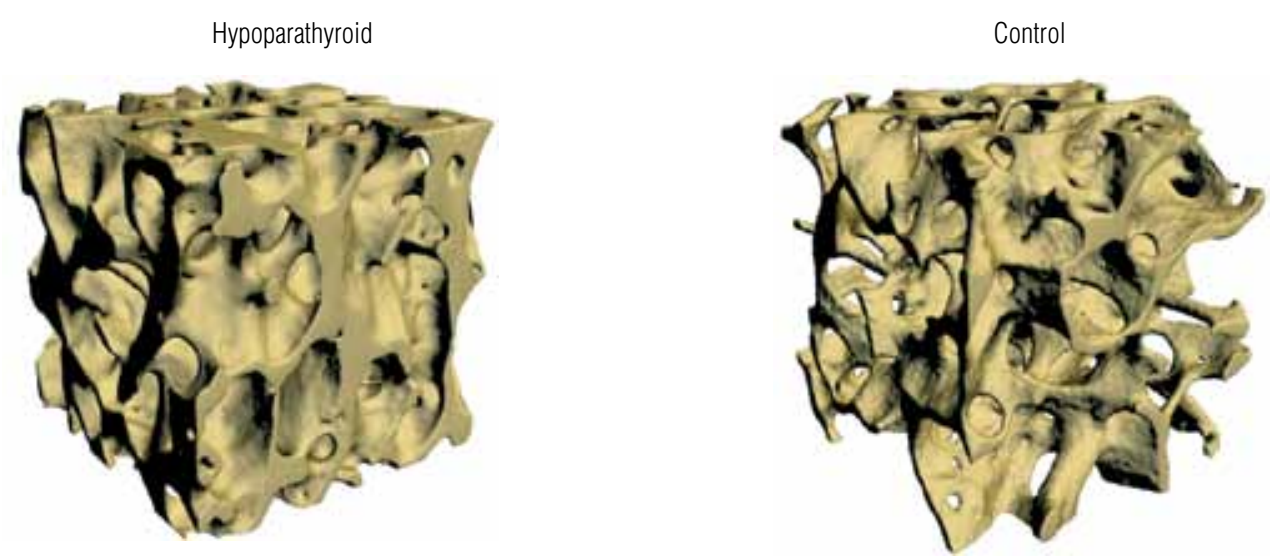

Figure 1B. 3-D $\mu C T$ image of iliac crest biopsy in a representative hypoparathyroid subject (left) and a normal control (right). 


\section{Material properties of bone in hypoparathyroidism}

To understand material properties of the hypoparathyroid skeleton, we subjected the transiliac biopsies to quantitative backscattered electron imaging (qBEI) and Fourier transform infrared imaging (FTIRI - Figures $2 \mathrm{~A}$ and $2 \mathrm{~B})$. Bone mineralization density distribution (BMDD) outcomes as determined by qBEI showed a positive correlation with duration of the disease $(\mathrm{Ca}-$ Peak, $\mathrm{r}=0.48, \mathrm{p}=0.04$; CaHigh, $\mathrm{r}=0.55, \mathrm{P}=0.02)$, as well as increased inter-individual variation $(\mathrm{CV}+92 \%)$ in the hypoparathyroid subjects. On average, the data in the hypoparathyroid individuals did not differ from normal controls. In contrast, by FTIRI, the collagen crosslink ratio was significantly higher $(\mathrm{p}<0.001)$ in the hypoparathyroid subjects as compared to normal. Collagen cross-link ratio correlated significantly with qBEI outcomes that were related to the amount of mineral, as characterized by BMDD parameters (CaMean, $r=0.69$, $\mathrm{p}=0.001$; and CaPeak, $\mathrm{r}=0.66, \mathrm{p}=0.002)$. These data are consistent with the low turnover state of these individuals and suggest a skeleton that is in a low turnover state and has become mature, if not hypermature.

- Female, postoperative - Female, DiGeorge $\Delta$ Male, autoimmune \ Female, autoimmune $\circ$ Male, postoperative
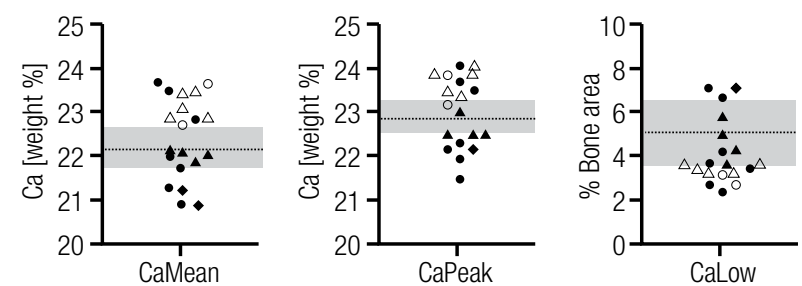

Figure 2A. Scatter plots of the five BMDD parameters measured in 19 hypoparathyroid patients. The patients are distinguished by categories, gender, and etiology. Grey band and dotted line in the background indicate $\mathrm{SD}$ and mean of the reference values.

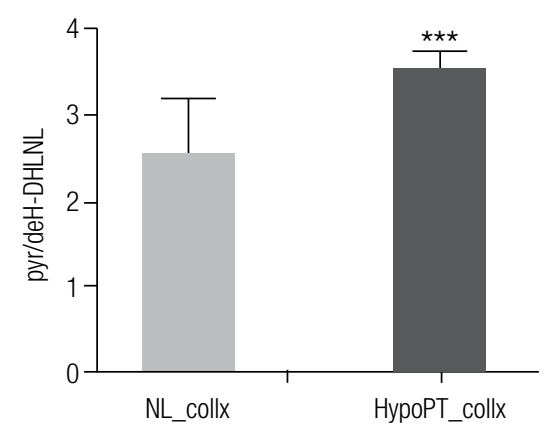

Figure 2B. FTIRI measurements in biopsies from the hypoparathyroid patients $(n=19)$. Collagen cross link ratio (pyr/deH-DHLNL) were assessed in trabecular bone (HypoPT_collx) and compared with a normal reference population (NL_collx).

\section{MANAGEMENT OF HYPOPARATHYROIDISM}

Conventional management of hypoparathyroidism consists of oral calcium and 1,25-dihydroxyvitamin D in relatively large amounts. While this approach can usually maintain a normal serum calcium level in these individuals, it can also be a challenge. Often there are major swings in either direction leading to symptomatic hypercalcemia or hypocalcemia. Some patients demonstrate heightened sensitivity to small changes in the serum calcium even without overtly wide biochemical swings. In addition, the use of relatively high amounts of oral calcium and vitamin D can lead to worsening hypercalciuria. This, in turn, can lead in some cases to nephrocalcinosis, nephrolithiasis or renal insufficiency (16-18).

A recent alternative therapeutic approach has become of interest in view of the availability of PTH for the treatment of osteoporosis. Since it is the parathyroid hormone that is missing in this disorder, it seems most reasonable to consider this therapeutic approach. In fact, hypoparathyroidism is the sole remaining endocrine deficiency disease for which the missing hormone is not available as a therapy. Moreover, reducing calcium and calcitriol requirements in hypoparathyroidism with the use of PTH could also potentially lessen the risks of hypercalcemia and hypercalciuria. An additional possible advantage is that PTH use could reduce the risk of soft tissue deposition of calcium (nephrocalcinosis, nephrolithiasis and possibly in other soft tissues).

Teriparatide, a PTH molecule foreshortened to an amino terminus region [PTH (1-34)], has been shown to maintain serum calcium in the normal range and to reduce urinary calcium excretion in hypoparathyroid subjects (19-21). Use of the native, full length molecule, $\mathrm{PTH}(1-84)$, has recently been investigated by us as another approach to the therapy of hypoparathyroidism. A dosing study was first performed to determine how much and with what frequency $\mathrm{PTH}(1-84)$ could be used to raise bone turnover levels in a robust manner but not higher than upper limits of normality. In our preliminary dosing study, we observed that a regimen of $100 \mu \mathrm{g}$ of $\mathrm{PTH}(1-84)$ administered every other day, met this goal better than daily or every third day use of $100 \mu \mathrm{g}$ of PTH(1-84). The results of a 2-year study are summarized here (22).

Throughout the 2-year clinical trial, requirements for supplemental calcium fell significantly from $3.03 \pm$ 
2.3 to $1.66 \pm 1.3 \mathrm{~g} /$ day $(\mathrm{p}<0.05$; Figure $3 \mathrm{~A})$. The number of subjects on calcium supplementation that was greater than $1.5 \mathrm{~g} / \mathrm{d}$ decreased from $22(73 \%)$ at study entry to $12(40 \%)$ at study conclusion. 1,25-dihydroxyvitamin $\mathrm{D}$ supplementation declined from the baseline mean of $0.68 \pm 0.5$ to $0.40 \pm 0.5 \mu \mathrm{g} /$ day $(\mathrm{p}<0.05$; Figure $3 \mathrm{~B})$. The number of subjects on a dose of 1,25-dihydroxyvitamin $\mathrm{D}$ that was greater than $0.25 \mu \mathrm{g} / \mathrm{d}$ fell from $25(83 \%)$ at study entry to $15(50 \%)$ at study conclusion. The number of subjects who did not require any 1,25-dihydroxyvitamin $\mathrm{D}$ increased from 1 to 8 . The reductions in the amounts of calcium and vitamin D supplementation were similar regardless of the etiology of the hypoparathyroidism. The number of subjects on hydrochlorothiazide for hypercalciuria decreased from 10 at baseline to 3 at study conclusion. Those who were on thiazides did not differ from the group in terms of baseline calcium and calcitriol supplementation.
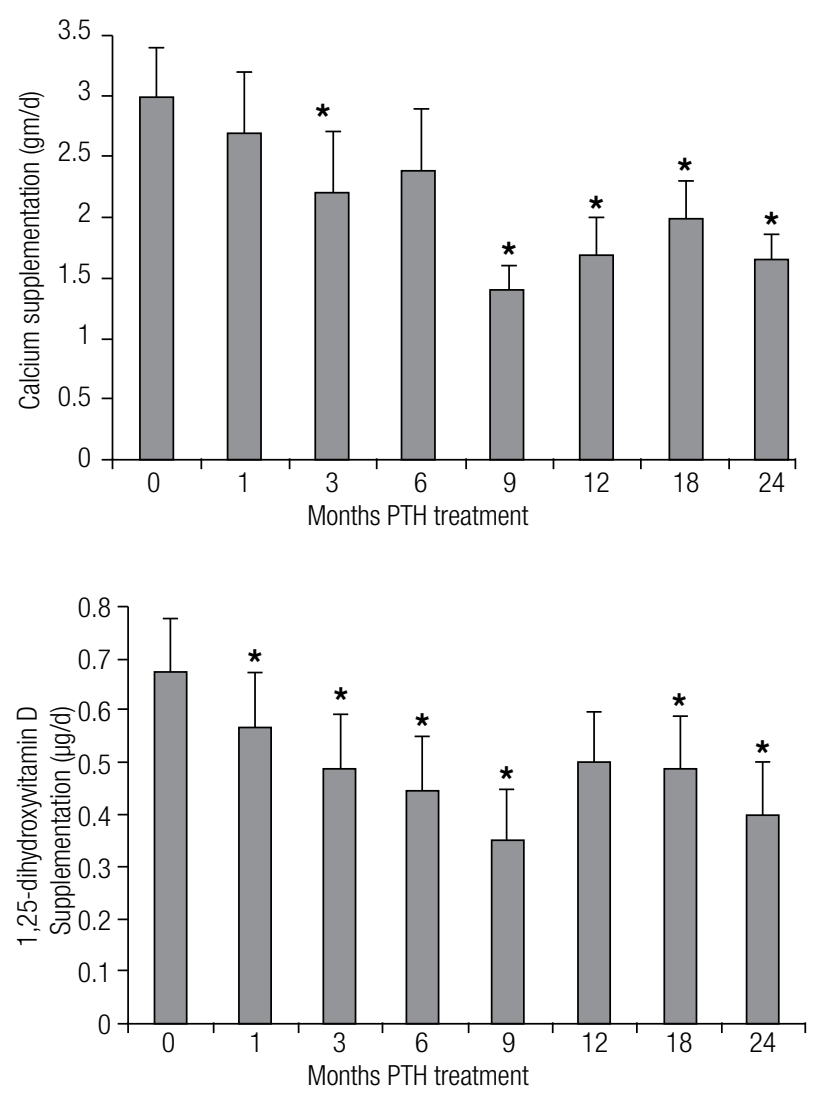

Figure 3. Changes in Calcium (3A) and 1,25-dihydroxyvitamin D (3B) Supplementation. Calcium requirements decreased at 3, 9, 12, 18 and 24 months from baseline, while 1,25-dihydroxyvitamin $D$ requirements decreased by 1 month. Data are mean $\pm S D$; ${ }^{*} p<0.05$ as comparison to baseline.

\section{SERUM AND URINARY CALCIUM LEVELS AND OTHER INDICES OF MINERAL METABOLISM}

Serum calcium concentration was maintained in the lower half of the normal range and during months 9 to 24 was not different from baseline values. Except for a minimal increase in serum calcium during the first 6 months, serum calcium values did not differ from baseline levels. Of the many determinations of serum calcium, only $4 \%$ of all values were above the normal range with the highest value recorded in one subject once at $3.2 \mathrm{mmol} / \mathrm{L}$. 24-hour urinary calcium excretion was generally unchanged.

Serum phosphate levels fell from $1.44 \pm 0.2$ to 1.29 $\pm 0.2 \mathrm{mmol} / \mathrm{L}(\mathrm{p}<0.05)$. 25-hydroxyvitamin $\mathrm{D}$ levels decreased significantly from baseline $(150.0 \pm 165$ to $81.1 \pm 45 \mathrm{nmol} / \mathrm{L} ; \mathrm{p}<0.05)$. 1,25-dihydroxyvitamin D levels did not change $(97.2 \pm 52$ to $111.2 \pm$ $60 \mathrm{pmol} / \mathrm{L})$. Total alkaline phosphatase activity increased significantly from $66 \pm 18 \mathrm{U} / \mathrm{L}$ at baseline to $85 \pm 22 \mathrm{U} / \mathrm{L}$ by month 3 and remained significantly above baseline at month $24(73 \pm 21 \mathrm{U} / \mathrm{L} ; \mathrm{p}<0.05)$. The new steady state level of the alkaline phosphatase activity was well within normal limits. Magnesium fell minimally $(0.74 \pm 0.1$ to $0.72 \pm 0.1 \mathrm{mmol} / \mathrm{L} ; \mathrm{p}$ $<0.05)$. Serum creatinine did not change significantly $(88.4 \pm 796$ to $79.6 \pm 796 \mu \mathrm{mol} / \mathrm{L} ; \mathrm{p}=\mathrm{NS})$; nor did GFR as calculated by MDRD $(74.9 \pm 21$ to $76.4 \pm 20$ $\mathrm{mL} / \mathrm{min} / 1.73 \mathrm{~m}^{2} ; \mathrm{p}=\mathrm{NS}$ ).

\section{BONE MINERAL DENSITY}

Lumbar spine BMD increased from baseline by $2.9 \pm$ $4 \%(\mathrm{p}<0.05)$ from $1.24 \pm 0.3$ to $1.27 \pm 0.3 \mathrm{~g} / \mathrm{cm}^{2}$ ( T score: $+1.7 \pm 2$ to $+1.9 \pm 2$; Figure 4$)$. Femoral neck BMD did not change significantly from baseline $(+0.95$ $\pm 0.2 \mathrm{~g} / \mathrm{cm}^{2}$; T score $0.7 \pm 2$; Figure 4$)$, while the distal $1 / 3$ radius BMD decreased by $2.4 \pm 4 \%(\mathrm{p}<0.05)$ $\left(+0.72 \pm 0.1\right.$ to $0.70 \pm 0.1 \mathrm{~g} / \mathrm{cm}^{2} ;$ T score $-0.03 \pm 2$ to $-0.26 \pm 1$; Figure 4).

\section{DISCUSSION}

It is clear from our experience that $\mathrm{PTH}(1-84)$ represents a promising approach to the management of patients with hypoparathyroidism. Requirements for supplemental calcium and 1,25-dihydroxyvitamin D were significantly reduced while maintaining normal, stable serum calcium concentrations. In line with the actions 
of PTH to be anabolic at cancellous bone and catabolic at cortical bone, BMD increased at the lumbar spine and decreased at the distal $1 / 3$ radius. Femoral neck BMD did not change.

Treatment of hypoparathyroidism with PTH is appealing because it provides the hormone that is missing in this disease. Replacement therapy with PTH should lead to a restoration of, or improvement in calcium homeostasis. Illustrating this point, we were able to maintain the serum calcium within the normal range, despite significantly reducing the intake of supplemental calcium and vitamin D. The observation that PTH is not associated with hypercalciuria has been seen also when $\mathrm{PTH}(1-34)$ was used in hypoparathyroidism (20). With another dosing regimen, perhaps, urinary calcium excretion might decrease, a finding that would take advantage of the physiologic actions of PTH to conserve urinary calcium excretion.
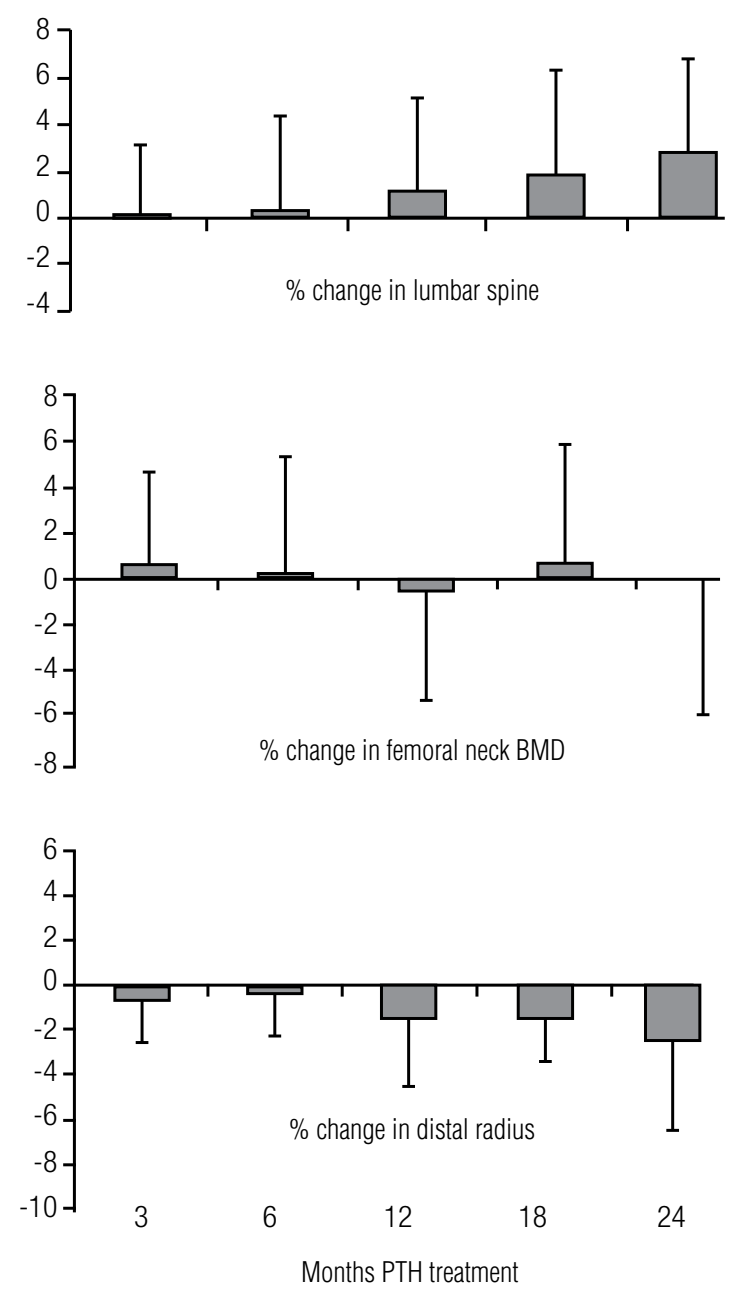

Figure 4. BMD Changes with PTH (1-84) therapy of hypoparathyroidism.
It is difficult to compare our results with the data of Winer and cols. (20) with $\mathrm{PTH}(1-34)$, because of the different dosages and frequencies of administration. In the study of Winer and cols. (19), there were no differences in BMD when the PTH group was compared to those who were treated with 1,25-dihydroxyvitamin D alone (19). Our results differ in that the lumbar spine BMD increased significantly. Since PTH is known to be anabolic for cancellous bone, these findings could indicate that new, younger bone is being formed as a result of PTH treatment. More detailed examination of skeletal features, using high resolution imaging or bone biopsy, would be necessary to elucidate which changes in microarchitectural parameters contribute to the increase in trabecular BMD. Such results, which are ongoing, will also be of great interest in terms of a comparison between effects of PTH as a therapy for osteoporosis or as replacement therapy for hypoparathyroidism. Along with the increase in lumbar spine BMD, we observed a decrease in the distal $1 / 3$ radius, a site of cortical bone. Again, these results speak to the effects of PTH to cause endosteal resorption, but they do not imply that bone is weakened, because salutary effects on microarchitecture and bone size could well provide biomechanical advantages despite the reduction in BMD. Again, more detailed skeletal assessment would be required to answer this question. Overall, these changes in trabecular and cortical skeletal compartments recall the pattern seen with PTH treatment of osteoporosis in individuals who do not have hypoparathyroidism (23).

\section{CONCLUSIONS}

Chronic hypoparathyroidism is associated with markedly abnormal skeletal microstructure, despite marked increases in bone mineral density. It is also met with a therapeutic challenge to maintain calcium levels with worsening hypercalciuria. Parathyroid hormone promises to improve abnormalities in the skeleton and to provide better biochemical control of this disease.

Acknowledgements: Funded, in part, by NIH grant: NIH DK069350.

Disclosure: John P. Bilezikian works as a Research Grant and Consultant for NPS Pharmaceuticals.

\section{REFERENCES}

1. Ahonen P, Myllarniemi S, Sipila I, Perheentupa J. Clinical variation of autoimmune polyendocrinopathy-candidiasis-ectodermal dystrophy (APECED) in a series of 68 patients. N Engl J Med. 1990;322:1829-36. 
2. Bilezikian JP. Primary hyperparathyroidism and hypoparathyroidism. In: Rakel R, Bope E, editors. Conn's Current Therapy 2008. 1st ed. Philadelphia: Saunders-Elsevier; 2008. p. 634-7.

3. Rubin MR, Levine M. Hypoparathyroidism and pseudohypoparathyroidism. In: Rosen C, editors. Primer on the metabolic bone diseases and disorders of mineral metabolism. Washington, DC: ASBMR; 2008. p. 354-61.

4. Shoback D. Clinical practice. Hypoparathyroidism. N Engl J Med. 2008;359:391-403.

5. Sunthornthepvarakul T, Churesigaew S, Ngowngarmratana S. A novel mutation of the signal peptide of the preproparathyroid hormone gene associated with autosomal recessive familial isolated hypoparathyroidism. J Clin Endocrinol Metab. 1999;84:3792-6.

6. Sullivan KE. DiGeorge syndrome/velocardiofacial syndrome: the chromosome 22q11.2 deletion syndrome. Adv Exp Med Biol. 2007;601:37-49.

7. Brown EM. Anti-parathyroid and anti-calcium sensing receptor antibodies in autoimmune hypoparathyroidism. Endocrinol Metab Clin North Am. 2009;38:437-45.

8. Abugassa S, Nordenstrom J, Eriksson S, Sjoden G. Bone mineral density in patients with chronic hypoparathyroidism. J Clin Endocrinol Metab. 1993;76:1617-21.

9. Fujiyama $\mathrm{K}$, Kiriyama T, Ito $\mathrm{M}$, et al. Attenuation of postmenopausal high turnover bone loss in patients with hypoparathyroidism. J Clin Endocrinol Metab. 1995;80:2135-8.

10. Seeman E, Wahner HW, Offord KP, Kumar R, Johnson WJ, Riggs BL. Differential effects of endocrine dysfunction on the axial and the appendicular skeleton. J Clin Invest. 1982;69:1302-9.

11. Touliatos JS, Sebes JI, Hinton A, McCommon D, Karas JG, Palmieri GM. Hypoparathyroidism counteracts risk factors for osteoporosis. Am J Med Sci. 1995;310:56-60.

12. Rubin MR, Dempster DW, Zhou H, Shane E, Nickolas T, Sliney J Jr, et al. Dynamic and structural properties of the skeleton in hypoparathyroidism. J Bone Miner Res. 2008;23:2018-24.
13. Silverberg SJ, Shane E, de la Cruz L, et al. Skeletal disease in primary hyperparathyroidism. J Bone Miner Res. 1989;4:283-91.

14. Rubin MR, Dempster DW, Zhou H, Shane E, NickolasT, Sliney J Jr, et al. Dynamic and structural properties of the skeleton in hypoparathyroidism. J Bone Miner Res. 2008;23:2018-24.

15. Rubin MR, Dempster DW, KohlerT, Stauber M, Zhou H, Shane E, et al. Three-dimensional cancellous bone structure in hypoparathyroidism. Bone 2010;46(1):190-5. [Epub 2009 Sep 25]

16. Christiansen C, Rodbro P, Christensen MS, Hartnack B, Transbol I. Deterioration of renal function during treatment of chronic renal failure with 1,25-dihydroxycholecalciferol. Lancet. 1978;2:700-3.

17. Kurokawa K. Calcium-regulating hormones and the kidney. Kidney Int. 1987;32:760-71.

18. Litvak J, Moldawer MP, Forbes AP, Henneman PH. Hypocalcemic hypercalciuria during vitamin $\mathrm{D}$ and dihydrotachysterol therapy of hypoparathyroidism. J Clin Endocrinol Metab. 1958;18:246-52.

19. Winer KK, Ko CW, Reynolds JC, Dowdy K, Keil M, Peterson D, et al. Long-term treatment of hypoparathyroidism: a randomized controlled study comparing parathyroid hormone-(1-34) versus calcitriol and calcium. J Clin Endocrinol Metab. 2003;88:4214-20.

20. Winer KK, Yanovski JA, Cutler GB Jr. Synthetic human parathyroid hormone 1-34 vs calcitriol and calcium in the treatment of hypoparathyroidism. JAMA. 1996;276:631-6.

21. Winer KK, Yanovski JA, Sarani B, Cutler GB Jr. A randomized, cross-over trial of once-daily versus twice-daily parathyroid hormone 1-34 in treatment of hypoparathyroidism. J Clin Endocrinol Metab. 1998;83:3480-6.

22. Rubin MR, Sliney Jr J, McMahon DJ, Silverberg SJ, Bilezikian JP. Therapy of hypoparathyroidism with intact parathyroid hormone. Osteoporosis Int. 2009. [In press]

23. Neer RM, Arnaud CD, Zanchetta JR, Prince R, Gaich GA, Reginster $J Y$, et al. Effect of parathyroid hormone (1-34) on fractures and bone mineral density in postmenopausal women with osteoporosis. N Engl J Med. 2001;344:1434-41. 